\title{
Principal Components Analysis of Raman Spectral Data for Screening of Hepatitis C Infection
}

\author{
A. Dita \\ University of Agriculture, Faisalabad, Pakistan \\ H. Nawaz \\ University of Agriculture, Faisalabad, Pakistan \\ T. Mahmood \\ University of Agriculture, Faisalabad, Pakistan
}

See next page for additional authors

Follow this and additional works at: https://arrow.tudublin.ie/nanolart

Part of the Pharmacology, Toxicology and Environmental Health Commons

\section{Recommended Citation}

Ditta, A., Nawaz, H., Mahood, T., Majeed, M., Tahir, M., Rashid, N., Muddassar, Al-Saadi, A. \& Byrne, H.J. (2019). Principal components analysis of Raman spectral data for screening of Hepatitis $C$ infection. Spectrochimica Acta Part A: Molecular and Biomolecular Spectroscopy, 221, 117173. doi:10.1016/ j.saa.2019.117173

This Article is brought to you for free and open access by the NanoLab at ARROW@TU Dublin. It has been accepted for inclusion in Articles by an authorized administrator of ARROW@TU Dublin. For more information, please contact arrow.admin@tudublin.ie, aisling.coyne@tudublin.ie,gerard.connolly@tudublin.ie.

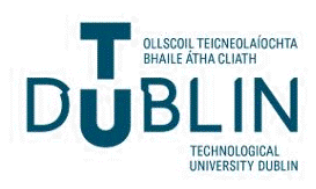




\section{Authors}

A. Dita, H. Nawaz, T. Mahmood, M. Tahir, N. Rashid, Muhammad Mudassar, A.A.H. Alsaadi, and Hugh J. Byrne

This article is available at ARROW@TU Dublin: https://arrow.tudublin.ie/nanolart/98 
Title:

Principal Components Analysis of Raman spectral data for screening of Hepatitis C infection

\section{Authors:}

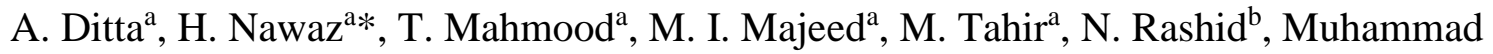
Mudassarc $^{\mathrm{c}}$, A. A. H Alsaadi ${ }^{\mathrm{d}}$ and H.J. Byrne

${ }^{\text {a }}$ Department of Chemistry, University of Agriculture, Faisalabad, Pakistan.

${ }^{\mathrm{b}}$ University of Central Punjab, Faisalabad campus, Faisalabad, Pakistan.

c.COMSATS University, Islamabad, Pakistan.

${ }^{\mathrm{d}}$ Department of Chemistry, King Fahd University of Petroleum \& Minerals, Dhahran 31261, KSA.

${ }^{\mathrm{e}}$ FOCAS Research Institute, Dublin Institute of Technology, Kevin Street, Dublin 8, Ireland.

*Corresponding Author: DrHaq Nawaz

E-mail: haqchemist@yahoo.com 


\begin{abstract}
In the current study, Raman spectroscopy is employed for the identification of the biochemical changes taking place during the development of Hepatitis C. The Raman spectral data acquired from the human blood plasma samples of infected and healthy individuals is analysed by Principal Components Analysis and the Raman spectral markers of the Hepatitis C Virus (HCV) infection are identified. Spectral changes include those associated with nucleic acidsat $720 \mathrm{~cm}^{-1}$, $1077 \mathrm{~cm}^{-1} 1678$ (C=O stretching mode of dGTP of RNA), $1778 \mathrm{~cm}^{-1}$ (RNA), with proteins at $1641 \mathrm{~cm}^{-1}$ (amide-I), $1721 \mathrm{~cm}^{-1}(\mathrm{C}=\mathrm{C}$ stretching of proteins $)$ and lipids at $1738 \mathrm{~cm}^{-1}(\mathrm{C}=\mathrm{O}$ of ester group in lipids). These differences in Raman spectral features of blood plasma samples of the patients and healthy volunteers can be associated with the development of the biochemical changes during HCV infection.
\end{abstract}

Keywords: Hepatitis C, blood plasma, Raman spectroscopy; Principal components analysis; 


\section{Introduction:}

Hepatitis $\mathrm{C}$ is caused by the infection of a virus and almost $3 \%$ of the world and $4.8 \%$ Pakistani population is affected by this disease (Shepard, Finelli et al. 2005; Lavanchy 2009; Ford, Kirby et al. 2012). Currently available screening techniques, like Enzyme Linked Immunosorbent Assay (ELISA), involve the detection of the antibodies and pathogens in the blood of the patients infected by Hepatitis C virus (HCV) (Kesli, Polat et al. 2011). Although, ELISA is very commonly employed, observation of the false positive and false negative results indicates difficulties in blood screening (Gretch 1997; Martin, Fabrizi et al. 1998; Schiff, de Medina et al. 1998).

Polymerase Chain Reaction (PCR) is currently considered as the gold standard technique for the direct detection of the HCV RNA, the most reliable disease marker, in blood serum or plasma (Raeymaekers 1993; Pawlotsky 2003).To achieve accurate results from this method, the reagents and the instrumentation employed must be of high quality and sensitivity, respectively. In this regard, it is important to mention that PCR based methods are considered more reliable than ELISA based methods (Enomoto, Nishiguchi et al. 2001; Swellam, Mahmoud et al. 2011), but the former technique is time consuming, less commonly available, laborious and expensive. This demands the development of more reliable, rapid, biochemical label free and automated diagnosis method which may be helpful for effective disease management.

Raman spectroscopy has been used for determining the biochemical changes in the biomacromolecules of cells and tissues, including lipids, proteins and DNA, simultaneously (Nawaz, Bonnier et al. 2010; Nawaz, Bonnier et al. 2011; Nawaz, Garcia et al. 2013). Moreover, the technique has been employed for the analysis of the body fluids, like blood plasma/serum and urine, for the diagnosis of the diseases (Neugebauer, Trenkmann et al. 2014; Pachaiappan, 
Prakasarao et al. 2017; Pappu, Prakasarao et al. 2017). The potential of Raman spectroscopy for the diagnosis of diseases which are caused by viral infections, such as dengue (Saleem, Bilal et al. 2013) and HPV (Ostrowska, Malkin et al. 2010; Ostrowska, Garcia et al. 2011)has also been demonstrated.

Although the diagnosis of $\mathrm{HCV}$ infection in blood serum/plasma samples from infected patients by employing Raman spectroscopy has been reported, these studies used Principal Component Analysis (PCA) for the comparison of normal versus HCV positive samples (Saade, Pacheco et al. 2008) and a Partial Least Squares Regression (PLSR) model for the prediction of the viral load (Nawaz, Rashid et al. 2017). In the present study, serologically characterised HCV positive blood plasma samples are divided into three different groups, for the purpose of comparison, namely low, medium and high viral load samples, and their Raman spectral data is compared with that of control/healthy samples by using PCA of these three degrees of infection of disease. The analysis identifies specific spectral markers which may be associated with the presence, as well as degree of infection.

\section{Materials and methods}

\section{Sample preparation}

Blood plasma samples from 10 healthy/control and 11 Hepatitis $\mathrm{C}$ patients with different viral load values, as described in Table 1, were collected from Allied Hospital, Faisalabad, Pakistan. These patients were diagnosed as infected with HCV by the Polymerase Chain Reaction (PCR) technique, and classified into three groups on the basis of viral load values, currently a gold standard for the diagnosis of Hepatitis, which quantified the HCV loads in the patient samples.

\section{Raman spectral acquisition}

A $20 \mu \mathrm{l}$ drop of each plasma sample was placed on an aluminium slide at room temperature and Raman spectra were acquired before the plasma sample had dried. The process of placing the 
$20 \mu 1$ drop on the aluminium slide was repeated 3 times by employing a clean aluminium slide each time for acquiring 20-25 spectra in total from each sample.

Raman spectral acquisition from all of the 10 healthy/control and $11 \mathrm{HCV}$ infected blood plasma samples was performed using a Raman spectrometer (Peak Seeker Pro-785; Agiltron, USA). The Peak Seeker Pro-785 utilizes a $785 \mathrm{~nm}$ diode laser as the excitation source, delivering a laser power of $\sim 60 \mathrm{~mW}$ at the sample. The laser was delivered to the sample through a 10× objective. The acquisition of the Raman spectra for all the samples was executed from 600 to $1800 \mathrm{~cm}^{-1}$ and 20-25 Raman spectra per sample were acquired with an acquisition time of 30 seconds.

\section{Data pre-processing}

All data processing of the Raman spectra was performed using MatLab 7.8 and established protocols (Nawaz, Bonnier et al. 2010). Data pre-processing included baseline correction, smoothing, vector normalisation, and substrate removal. All spectra, including substrate backgrounds, were vector normalised and smoothed using a Savitzky-Golay smoothing method (order 3, 17 point window). A rubber band correction for baseline removal for all the spectra was carried out and the substrate spectra were subtracted from each spectrum.

\section{Data analysis}

The Raman spectral features were analysed by comparing the mean Raman spectra of HCV infected blood plasma samples with healthy ones. The Raman peak assignments were taken from the literature, as detailed in Table 2. PCA was used to differentiate groups of the spectral data acquired for the different blood plasma samples determined by PCR to be positive for HCV infection, and to identify their characteristic spectroscopic signatures. PCA is a mathematical procedure involving the transformation of possibly correlated variables into a smaller number of uncorrelated variables, known as principal components (PC), basically to reduce the dimensionality of the data whilst maintaining their variability. The first principal component accounts for the dominant source of variability in the data, and each successive principal component accounts for the next highest source of the remaining variability. The loadings of the PC can be understood as the orthogonal dimensions of biochemical differences which facilitate separation of different groups of spectra of Raman data along their variability as each spectrum scores along these dimensions. 


\begin{tabular}{|l|l|l|}
\hline Sample name & Viral load value & Category \\
\hline HCV-1 & 20,718 & Low \\
\hline HCV-2 & 120,533 & Low \\
\hline HCV-3 & 132,152 & Low \\
\hline HCV-4 & 189,531 & Low \\
\hline HCV-5 & 387,823 & Medium \\
\hline HCV-6 & 410,358 & Medium \\
\hline HCV-7 & 442,365 & Medium \\
\hline HCV-8 & 846,668 & High \\
\hline HCV-9 & 873,417 & High \\
\hline HCV-10 & 907,874 & High \\
\hline HCV-11 & $1,718,359$ & High \\
\hline
\end{tabular}

Table 1: Viral load values of the HCV samples.

\begin{tabular}{|c|l|l|}
\hline Wave numbers $\left(\mathbf{c m}^{-\mathbf{1}}\right)$ & Peak assignments & References \\
\hline 616 & C-C twisting (protein) & $\begin{array}{l}\text { (Chan, } \\
\text { Taylor et al. } \\
2006)\end{array}$ \\
\hline 630 & $\begin{array}{l}\text { n(C-S) gauche (aminoacid } \\
\text { methionine) }\end{array}$ & $\begin{array}{l}\text { (Shetty, } \\
\text { Kendall et } \\
\text { al. 2006) }\end{array}$ \\
\hline 651 & $\begin{array}{l}\text { n(C-S) gauche (aminoacid } \\
\text { methionine) }\end{array}$ & $\begin{array}{l}\text { (Shetty, } \\
\text { Kendall et } \\
\text { al. 2006) }\end{array}$ \\
\hline 674 & $\begin{array}{l}\text { Ring breathing modes in the DNA } \\
\text { bases G/T }\end{array}$ & $\begin{array}{l}\text { (Chan, } \\
\text { Taylor et al. }\end{array}$ \\
\hline
\end{tabular}




\begin{tabular}{|c|c|c|}
\hline & & 2006) \\
\hline 703 & Cholesterol, cholesterol ester & $\begin{array}{l}\text { (Krafft, } \\
\text { Neudert et } \\
\text { al. 2005) }\end{array}$ \\
\hline 720 & Adenine & $\begin{array}{l}\text { (Jess, Smith } \\
\text { et al. 2007) }\end{array}$ \\
\hline 727 & Adenine base/DNA & $\begin{array}{l}\text { Kline and } \\
\text { Treado } \\
1997)\end{array}$ \\
\hline 751 & $\begin{array}{l}\text { Symmetric breathing of tryptophan } \\
\text { (protein assignment) }\end{array}$ & $\begin{array}{l}\text { (Stone, } \\
\text { Kendall et } \\
\text { al. 2002; } \\
\text { Huang, } \\
\text { McWilliams } \\
\text { et al. 2003; } \\
\text { Cheng, Liu } \\
\text { et al. 2005) }\end{array}$ \\
\hline 761 & Tryptophan, d (ring) & $\begin{array}{l}\text { (Shetty, } \\
\text { Kendall et } \\
\text { al. 2006) }\end{array}$ \\
\hline $737-73$ & $\begin{array}{l}\text { Lactic acid, DNA, Tryptophan, d } \\
\text { (ring) }\end{array}$ & $\begin{array}{l}\text { (Binoy, } \\
\text { Abraham et } \\
\text { al. 2004; } \\
\text { Shetty, } \\
\text { Kendall et } \\
\text { al. 2006) }\end{array}$ \\
\hline $785 / 788$ & Phosphodiester bands in DNA/RNA & $\begin{array}{l}\text { (Notingher, } \\
\text { Green et al. } \\
2004 \text { ) }\end{array}$ \\
\hline $810 / 815$ & $\begin{array}{l}\text { Proline, hydroxyproline, tyrosine, } \\
\text { RNA }\end{array}$ & $\begin{array}{l}\text { (Cheng, Liu } \\
\text { et al. 2005) }\end{array}$ \\
\hline 830 & Proline & $\begin{array}{l}\text { (Cheng, Liu } \\
\text { et al. 2005) }\end{array}$ \\
\hline
\end{tabular}




\begin{tabular}{|c|c|c|}
\hline 850 & $\begin{array}{l}\text { Most probably due to single bond } \\
\text { stretching } \\
\text { vibrations for the amino acids and } \\
\text { valine and } \\
\text { polysaccharides }\end{array}$ & $\begin{array}{l}\text { (Cheng, Liu } \\
\text { et al. 2005) }\end{array}$ \\
\hline 857 & Tyrosine, collagen & $\begin{array}{l}\text { (Stone, } \\
\text { Kendall et } \\
\text { al. 2004) }\end{array}$ \\
\hline 880 & Tryptophan, d(ring) & $\begin{array}{l}\text { (Shetty, } \\
\text { Kendall et } \\
\text { al. 2006) }\end{array}$ \\
\hline 900 & $\begin{array}{l}\text { Monosaccharides (b-glucose), (C-O- } \\
\text { C) skeletal } \\
\text { Mode }\end{array}$ & $\begin{array}{l}\text { (Shetty, } \\
\text { Kendall et } \\
\text { al. 2006) }\end{array}$ \\
\hline 911 & Glucose & $\begin{array}{l}\text { (Krafft, } \\
\text { Neudert et } \\
\text { al. 2005) }\end{array}$ \\
\hline 922 & Collagen & $\begin{array}{l}\text { (Frank, } \\
\text { McCreery et } \\
\text { al. 1995) }\end{array}$ \\
\hline 934 & C-C stretching/protein assignment & $\begin{array}{l}\text { (Stone, } \\
\text { Kendall et } \\
\text { al. 2004) }\end{array}$ \\
\hline 951 & $\mathrm{~ns}\left(\mathrm{CH}_{3}\right)$ of proteins & $\begin{array}{l}\text { (Lakshmi, } \\
\text { Kartha et al. } \\
\text { 2002) }\end{array}$ \\
\hline 958 & $\begin{array}{l}\text { Hydroxyapatite, carotenoid, } \\
\text { cholesterol }\end{array}$ & $\begin{array}{l}\text { (Stone, } \\
\text { Kendall et } \\
\text { al. 2004) }\end{array}$ \\
\hline 991 & $\mathrm{C}-\mathrm{O}$ ribose, $\mathrm{C}-\mathrm{C}$ & $\begin{array}{l}\text { (Dukor } \\
\text { 2002) }\end{array}$ \\
\hline 1005 & Phenylalanine, C-C skeletal & $\begin{array}{l}\text { (Su, Ho et } \\
\text { al. 2006) }\end{array}$ \\
\hline
\end{tabular}




\begin{tabular}{|c|c|c|}
\hline 1031 & $\begin{array}{l}\mathrm{d}(\mathrm{C}-\mathrm{H}) \text {, phenylalanine (protein } \\
\text { assignment) }\end{array}$ & $\begin{array}{l}\text { (Huang, } \\
\text { McWilliams } \\
\text { et al. 2003) }\end{array}$ \\
\hline 1045 & $\begin{array}{l}\text { (symmetric stretching vibration of } \\
\mathrm{PO}_{4}\end{array}$ & $\begin{array}{l}\text { (Cheng, Liu } \\
\text { et al. 2005) }\end{array}$ \\
\hline 1059 & Lipids & $\begin{array}{l}\text { (Dukor } \\
2002)\end{array}$ \\
\hline 1077 & $\mathrm{PO}_{2} \mathrm{RNA}$ & $\begin{array}{l}\text { (Huang, } \\
\text { McWilliams } \\
\text { et al. 2003) }\end{array}$ \\
\hline 1089 & Phospholipids & $\begin{array}{l}\text { (Huang, } \\
\text { McWilliams } \\
\text { et al. 2003) }\end{array}$ \\
\hline 1157 & $\begin{array}{l}\text { In-plane vibrations of the conjugated } \\
\mathrm{C}=\mathrm{C}-\mathrm{C}\end{array}$ & $\begin{array}{l}\text { (Puppels, } \\
\text { Garritsen et } \\
\text { al. 1993) }\end{array}$ \\
\hline 1175 & $\mathrm{C}-\mathrm{H}$ bending, tyrosine & $\begin{array}{l}\text { (Ruiz-Chica } \\
\text {, Medina et } \\
\text { al. 2004) }\end{array}$ \\
\hline $1200-50$ & Amide III (proteins) & $\begin{array}{l}\text { (Notingher, } \\
\text { Green et al. } \\
2004 \text { ) }\end{array}$ \\
\hline 1214 & Stretching of C-N & $\begin{array}{l}\text { (Naumann } \\
1998)\end{array}$ \\
\hline 1222 & $\left(\mathrm{PO}_{2}\right)$, nucleic acids & $\begin{array}{l}\text { (Huang, } \\
\text { McWilliams } \\
\text { et al. 2003) }\end{array}$ \\
\hline $1311-1361$ & $\mathrm{CH}_{3} \mathrm{CH}_{2}$ wagging mode of collagen & $\begin{array}{l}\text { (Stone, } \\
\text { Kendall et } \\
\text { al. 2004) }\end{array}$ \\
\hline 1319 & Guanine & $\begin{array}{l}\text { (Ruiz-Chica } \\
\text {, Medina et }\end{array}$ \\
\hline
\end{tabular}




\begin{tabular}{|c|c|c|}
\hline & & al. 2004) \\
\hline 1322 & $\mathrm{CH}_{3} \mathrm{CH}_{2}$ twisting & $\begin{array}{l}\text { (Huang, } \\
\text { McWilliams } \\
\text { et al. 2003) }\end{array}$ \\
\hline 1344 & CH stretching & $\begin{array}{l}\text { (Farquharso } \\
\text { n, Shende et } \\
\text { al. 2005) }\end{array}$ \\
\hline 1355 & Guanine & $\begin{array}{l}\text { (Ruiz-Chica } \\
\text {, Medina et } \\
\text { al. 2004) }\end{array}$ \\
\hline 1390 & $\mathrm{CH}$ rocking & $\begin{array}{l}\text { (Schulz and } \\
\text { Baranska } \\
\text { 2007) }\end{array}$ \\
\hline 1424 & Deoxyribose & $\begin{array}{l}\text { (Ruiz-Chica } \\
\text {, Medina et } \\
\text { al. 2004) }\end{array}$ \\
\hline 1440 & $\mathrm{CH}_{2}$ and $\mathrm{CH}_{3}$ deformation vibrations & $\begin{array}{l}\text { (Hanlon, } \\
\text { Manoharan } \\
\text { et al. 2000) }\end{array}$ \\
\hline 1465 & Lipids & $\begin{array}{l}\text { (Lakshmi, } \\
\text { Kartha et al. } \\
\text { 2002) }\end{array}$ \\
\hline $1481-1562$ & Amide II & $\begin{array}{l}\text { (Dukor } \\
2002)\end{array}$ \\
\hline 1484 & $\begin{array}{l}\text { G, A (ring breathing modes in the } \\
\text { DNA bases) }\end{array}$ & $\begin{array}{l}\text { (Chan, } \\
\text { Taylor et al. } \\
\text { 2006) }\end{array}$ \\
\hline 1489 & DNA & $\begin{array}{l}\text { (Malini, } \\
\text { Venkatakris } \\
\text { hna et al. } \\
\text { 2006) }\end{array}$ \\
\hline 1502 & $\mathrm{C}=\mathrm{C}$ stretching in benzenoid ring & (Naumann \\
\hline
\end{tabular}




\begin{tabular}{|c|c|c|}
\hline & & 1998) \\
\hline 1522 & $\mathrm{C}=\mathrm{C}-$ carotenoid & $\begin{array}{l}\text { (Stone, } \\
\text { Kendall et } \\
\text { al. 2004) }\end{array}$ \\
\hline 1537 & Amide carbonyl group vibrations & $\begin{array}{l}\text { (Wood, } \\
\text { Quinn et al. } \\
\text { 1998) }\end{array}$ \\
\hline 1578 & Guanine (N3) & $\begin{array}{l}\text { (Ruiz-Chica } \\
\text {, Medina et } \\
\text { al. 2004) }\end{array}$ \\
\hline 1602 & Amide I band of proteins & $\begin{array}{l}\text { (Sigurdsson, } \\
\text { Philipsen et } \\
\text { al. 2004; } \\
\text { Chan, } \\
\text { Taylor et al. } \\
\text { 2006) }\end{array}$ \\
\hline 1620 & $\begin{array}{l}\mathrm{n}(\mathrm{C}=\mathrm{C}) \text {, tryptophan (protein } \\
\text { assignment) }\end{array}$ & $\begin{array}{l}\text { (Huang, } \\
\text { McWilliams } \\
\text { et al. 2003) }\end{array}$ \\
\hline 1641 & Amide I (alpha-helix) & $\begin{array}{l}\text { (Stone, } \\
\text { Kendall et } \\
\text { al. 2004) }\end{array}$ \\
\hline 1676 & Amide I (beta-sheet) & $\begin{array}{l}\text { (Lakshmi, } \\
\text { Kartha et al. } \\
\text { 2002). }\end{array}$ \\
\hline 1678 & $\begin{array}{l}\mathrm{C}=\mathrm{O} \text { stretching mode of } \mathrm{dGTP} \text { of } \\
\text { RNA }\end{array}$ & $\begin{array}{l}\text { (D'Amico, } \\
\text { Cammisuli } \\
\text { et al. 2015) }\end{array}$ \\
\hline 1708 & $\begin{array}{l}\mathrm{n}(\mathrm{C}=\mathrm{O}) \mathrm{OH} \text { (amino acids aspartic \& } \\
\text { glutamic } \\
\text { acid) }\end{array}$ & $\begin{array}{l}\text { (Shetty, } \\
\text { Kendall et } \\
\text { al. 2006) }\end{array}$ \\
\hline 1721 & $\mathrm{C}=\mathrm{O}$ stretching/proteins & $\begin{array}{l}\text { (Movasaghi, } \\
\text { Rehman et }\end{array}$ \\
\hline
\end{tabular}




\begin{tabular}{|l|l|l|}
\hline & & al. 2007) \\
\hline 1729 & Ester group & $\begin{array}{l}\text { (Krafft, } \\
\text { Neudert et } \\
\text { al. 2005) }\end{array}$ \\
\hline 1738 & Lipids & $\begin{array}{l}\text { (Dukor } \\
2002)\end{array}$ \\
\hline 1749 & C=O stretching & $\begin{array}{l}\text { (Malini, } \\
\text { Venkatakris } \\
\text { hna et al. } \\
2006)\end{array}$ \\
\hline 1765 & C=O sym stretch; part of doublet & $\begin{array}{l}\text { (Schrader } \\
2008)\end{array}$ \\
\hline 1778 & C=O stretch & (Schrader \\
& & 2008) \\
\hline 1783 & C=O stretch & (Schrader \\
& & \\
\hline & & \\
\hline
\end{tabular}

Table 2: Peak assignments of the Raman spectral features.

\section{Results:}

Figure 1 shows the mean Raman spectra of samples of healthy (a) and HCV positive blood plasma samples with low (b), medium (c) and high (d) viral load values. The Raman spectral features present in mean Raman spectra of blood plasma samples of healthy individuals (a) include those assigned to proteins, at $651 \mathrm{~cm}^{-1}$ (C-S stretching of amino acid), $674 \mathrm{~cm}^{-1}(\mathrm{C}-\mathrm{S}$ stretching), $727 \mathrm{~cm}^{-1}$ (C-C stretching), 737-773 $\mathrm{cm}^{-1}$ (C-S stretching, tryptophan), 1311-1361 $\mathrm{cm}^{-1}$ (amide, tryptophan), $880 \mathrm{~cm}^{-1}$ (tryptophan ring), $934 \mathrm{~cm}^{-1}$ (C-C backbone of proteins /alpha helix stretching), $\quad 1175 \mathrm{~cm}^{-1}\left(\mathrm{C}-\mathrm{H}\right.$ bending, tyrosine), $1481-1562 \mathrm{~cm}^{-1}$ (Amide II), $1602 \mathrm{~cm}^{-}$ ${ }^{1}$ (phenylalanine), $1641 \mathrm{~cm}^{-1}$ (amide-I). Moreover, other Raman features present in healthy spectra can be assigned to lipids, including those at $958 \mathrm{~cm}^{-1}$ (C-C stretching of lipids), $1059 \mathrm{~cm}^{-1}$ (C-C 
str./lipids), 1390 (C-N rocking), $1620 \mathrm{~cm}^{-1}$ (C-C stretching), $1729 \mathrm{~cm}^{-1}$ (ester group) and 1738 $\mathrm{cm}^{-1}(\mathrm{C}=\mathrm{O}$ of ester group in lipids). Notably, no Raman features associated with DNA/RNA are evident in the healthy blood plasma samples.

To highlight the changes in the mean Raman spectra of $\mathrm{HCV}$ positive samples, he peak assignments have been labelled in Figures 1 (b-c) with; red boxes for prominent and striking differences in different viral load values, rectangles for intensity changes and vertical lines for other differences.

The peak intensities of the above mentioned protein and lipids related peaks are increasing in (b), (c) and (d) with increase in degree of infection. Now, the most striking differences, observed in the mean Raman spectra, are the Raman spectral features which are solely observed for the HCV positive samples including those at $720 \mathrm{~cm}^{-1}$ (adenine), $1077 \mathrm{~cm}^{-1}$ ( $\mathrm{PO}_{2}$ stretching of RNA), 1678 $\mathrm{cm}^{-1}\left(\mathrm{C}=\mathrm{O}\right.$ stretching mode of dGTP of RNA), $1778 \mathrm{~cm}^{-1}$ (RNA), 1641 (amide-I), $1721 \mathrm{~cm}^{-}$ ${ }^{1}\left(\mathrm{C}=\mathrm{C}\right.$ stretching of proteins)and $1738 \mathrm{~cm}^{-1}(\mathrm{C}=\mathrm{O}$ of ester group in lipids $)$. These Raman features are potentially spectral markers for the presence of infection of $\mathrm{HCV}$ in the blood plasma samples. 


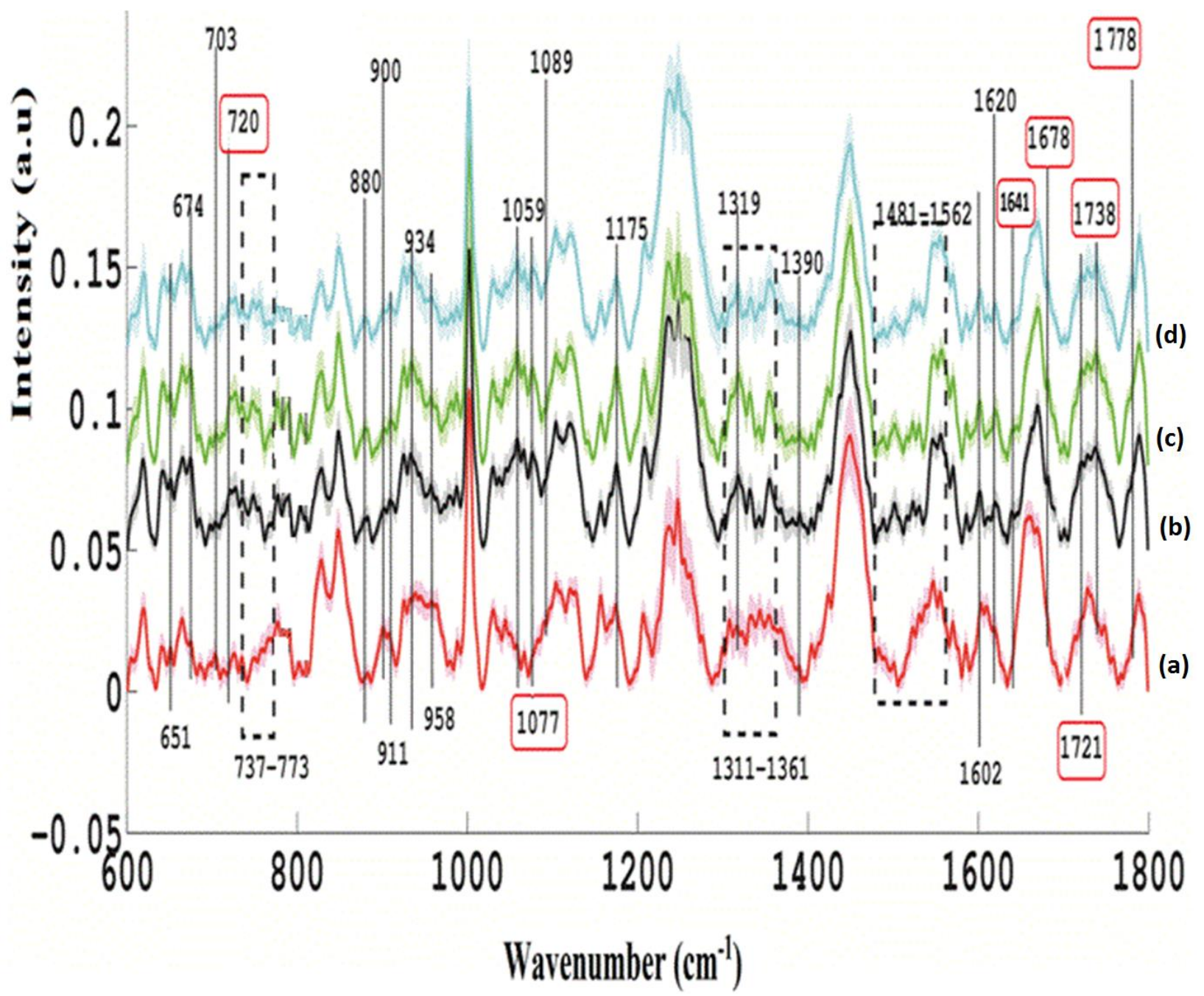

Figure 1:Mean Raman spectra of healthy and HCV positive blood plasma samples with increasing viral load values; healthy (a), low viral load (b), medium viral load (c) and high viral load (d) as described in Table 1.(Vertical lines with red box are for striking differences, without red box are showing intensity changes and doted box for bands and pattern change).

In Figure 2, mean difference spectra, healthy minus HCV positive blood plasma samples, of different viral load values which, for the purpose of comparison (Table-1), are divided into three classes including low (a), medium (b) and high (c), are shown. In the mean difference spectra, the differences in Raman spectral features associated with 3 different ranges of infection levels of HCV have been observed, and labeled. The difference spectra confirm the observations of Figure 1,as the Raman spectral features which feature prominently in the HCV positive samples, 
including those at720 $\mathrm{cm}^{-1}$ (adenine), and $1077 \mathrm{~cm}^{-1}\left(\mathrm{PO}_{2}\right.$ stretching of RNA), $1678 \mathrm{C}=\mathrm{O}$ stretching mode of dGTP of RNA, $1778 \mathrm{~cm}^{-1}$ (RNA), 1641 (amide-I), $1721 \mathrm{~cm}^{-1}(\mathrm{C}=\mathrm{C}$ stretching of proteins)and $1738 \mathrm{~cm}^{-1}$ ( $\mathrm{C}=\mathrm{O}$ of ester group in lipids), appear only in the $\mathrm{HCV}$ positive samples and hence maybe attributable to RNA stretching of the hepatitis $\mathrm{C}$ virus itself. These spectral features can be considered as direct markers of the viral infection in addition to those which are associated with the development of the biochemical changes during $\mathrm{HCV}$ infection. Clear differences in peak intensities at 616 (C-C twisting of proteins), 630 (C-S of amino acid methionine), 751 (symmetric breathing of tryptophan), 857 (Tyrosine), 951 ( $\mathrm{CH}$ stretching of protein alpha-helix), 1031, 1045, 1214 (stretching of $\mathrm{C}-\mathrm{N}), 1440\left(\mathrm{CH}_{2}\right.$ and $\mathrm{CH}_{3}$ deformation), 1465 (CH stretching of lipids), 1484 (G, A/RNA bases), 1522 (C=C- carotenoid), 1708 and 1765 ( $\mathrm{C}=\mathrm{O}$ of amino acids), and $1783 \mathrm{~cm}^{-1}$ are observed. These differences indicate the progression of the HCV infection from low to medium and high viral loads

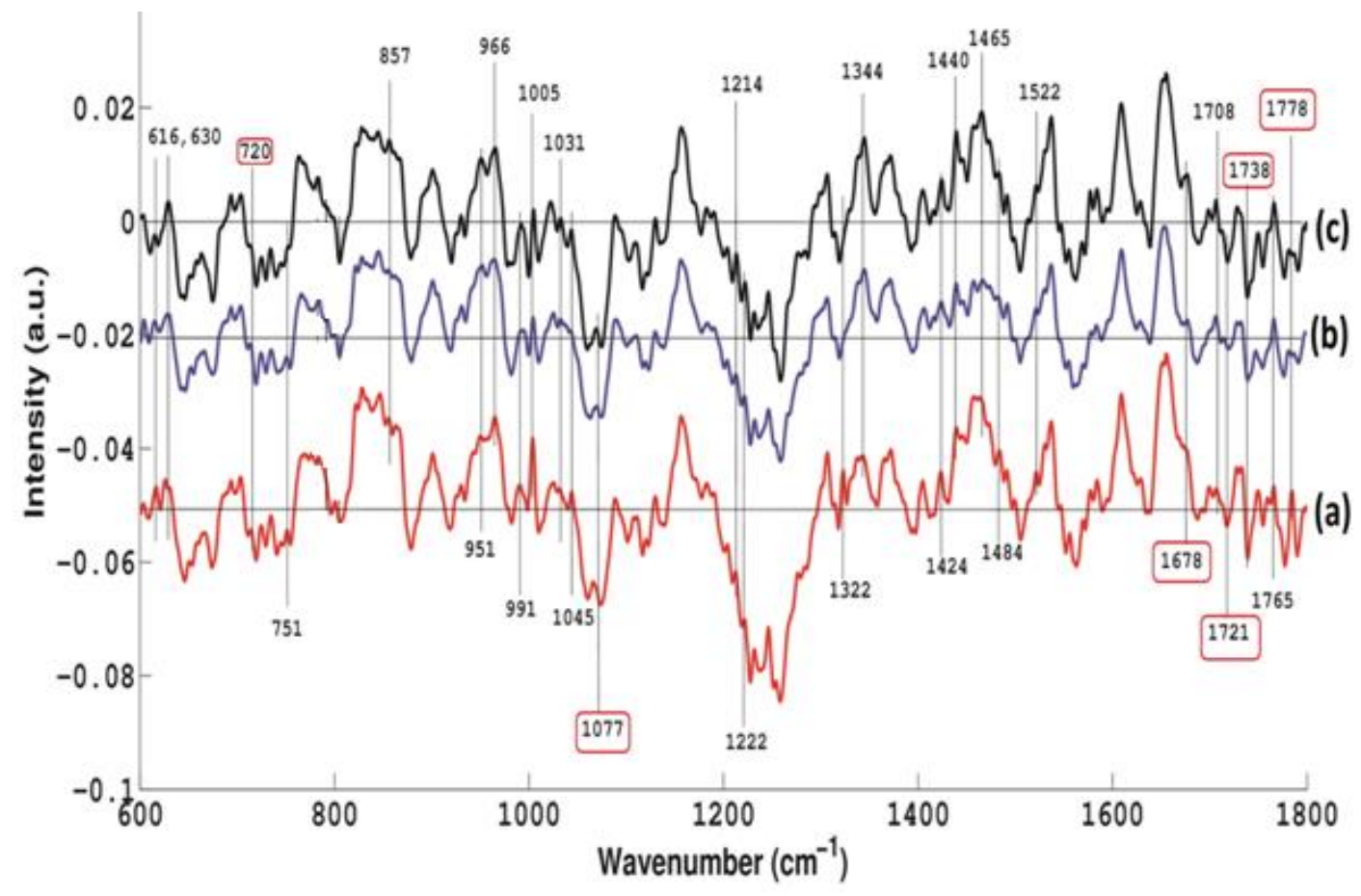

Figure 2: Mean difference Raman spectra of three classes of HCV samples including low (a), medium (b) and high (c) viral loads as described in Table-1. Spectra are off-set for clarity. 

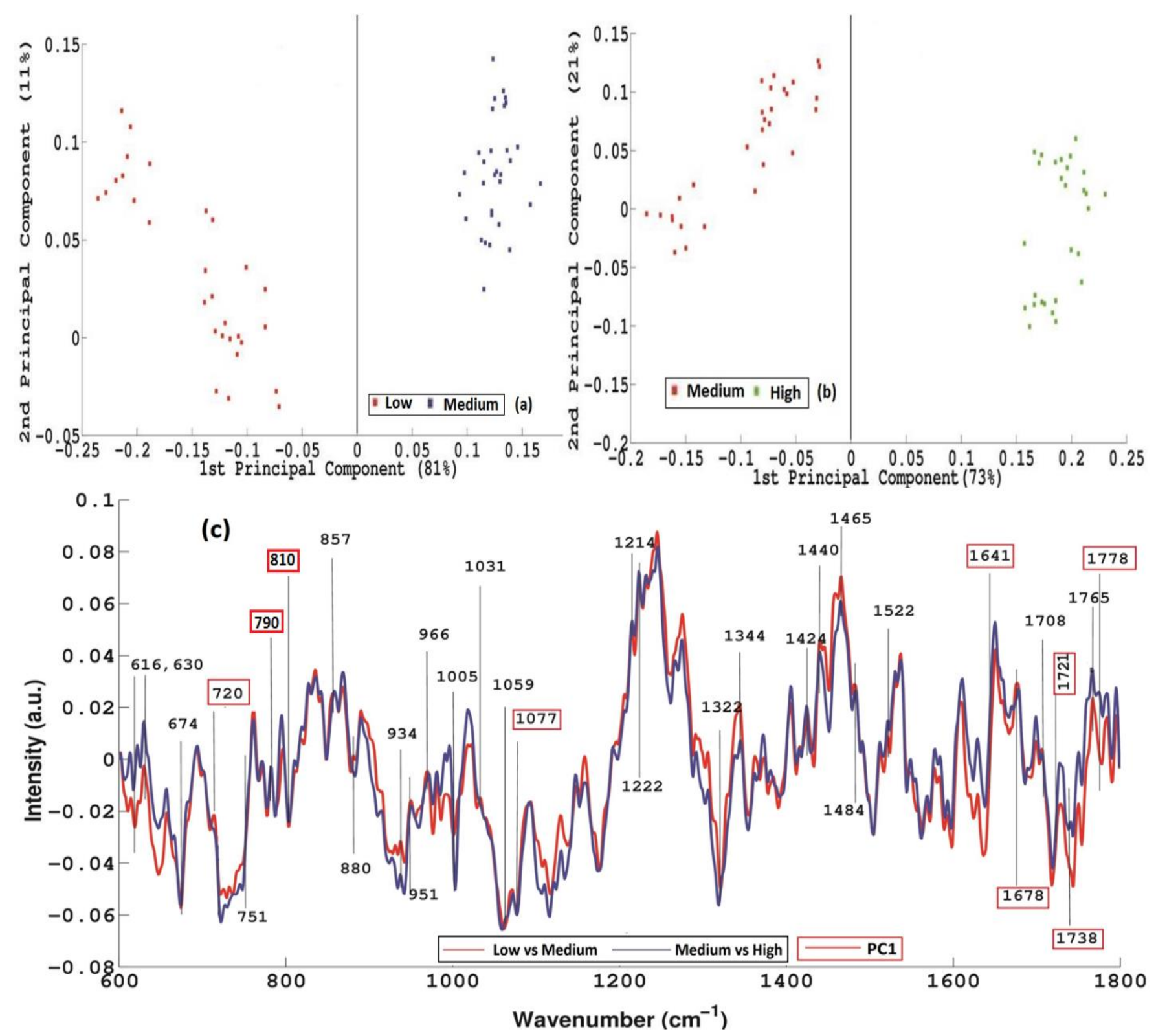

Figure 3 PCA scatter plots of Raman spectral data of different categories of HCV samples according to viral load values including low versus medium (a), medium versus high (b) and their respective PCA loadings.

In Figure 3 (a, b and c) PCA scatter plots and loadings of Raman spectral data of different categories of HCV samples according to viral load values including low (HCV-2), medium (HCV-5 and HCV-7) and high (HCV-11), as detailed in Table-1, are presented. The separation between the Raman spectra of HCV confirmed blood plasma samples of different categories of $\mathrm{HCV}$ samples according to viral load values is observed along PC-1.The Raman spectral features 
which are on the positive side are associated with low to high viral loads. In this regard, those Raman spectral features which have higher intensities with the severity of disease include those at720 $\mathrm{cm}^{-1}$ (adenine), $1077 \mathrm{~cm}^{-1}$ ( $\mathrm{PO}_{2}$ stretching of RNA), $1678 \mathrm{C}=\mathrm{O}$ stretching mode of dGTP of RNA, $1778 \mathrm{~cm}^{-1}$ (RNA), 1641 (amide-I), $1721 \mathrm{~cm}^{-1}\left(\mathrm{C}=\mathrm{C}\right.$ stretching of proteins)and $1738 \mathrm{~cm}^{-1}$ $(\mathrm{C}=\mathrm{O}$ of ester group in lipids.

Principal components analysis (PCA) was performed on the Raman spectral data of the ten controls/ healthy and eleven confirmed HCV samples, having different viral load values. In the PCA scatter plot, Figure 4 (a), the blue and red dots represent Raman spectra of HCV positive and healthy blood plasma samples, respectively, which are largely clustered on the positive and negative sides of PC-1 respectively, which accounts for $79 \%$ of the variance, while PC-2 accounts for only $7 \%$. The differentiation between these two different groups of Raman spectra supports the proposal that Raman spectroscopy has great potential to differentiate the blood plasma samples of the healthy and HCV positive individuals on the basis of the biochemical changes with reference to their viral load values of $\mathrm{HCV}$.

To understand the basis of the discrimination in the PCA scatter plot, the loadings of PC-1 are presented in Figure 4 (b). The positive loadings (positive side from separating line at zero) are associated with the Raman spectral data of the HCV positive samples while the negative loadings are associated with the healthy samples. Notably, (in Figure 4) the PCA loadings including those at $674 \mathrm{~cm}^{-1}$, associated with the T/G of RNA,720 $\mathrm{cm}^{-1}$ (adenine) and $1077 \mathrm{~cm}^{-1}\left(\mathrm{PO}_{2}\right.$ stretching of RNA), $1678 \mathrm{~cm}^{-1} \mathrm{C}=\mathrm{O}$ stretching mode of dGTP of RNA, $1778 \mathrm{~cm}^{-1}$ (RNA), 1641 (amide-I), $1721 \mathrm{~cm}^{-1}(\mathrm{C}=\mathrm{C}$ stretching of proteins $)$ and $1738 \mathrm{~cm}^{-1}(\mathrm{C}=\mathrm{O}$ of ester group in lipids $)$ are associated with the HCV positive samples. These observations once again confirm the results explained in the previous Figures and prove the ability of the Raman spectroscopy to identify the biochemical changes taking place during HCV infection. The observation of these Raman features as positive loadings indicate their association with the HCV RNA hence to the development of the HCV infection due to increasing viral load. Moreover, some other Raman spectral features/changes are also observed with a reduction in the their peak intensity or are not present in the control/healthy samples and are well developed in positive blood plasma samples indicated by the wave numbers including $880 \mathrm{~cm}^{-1}$ ( associated with tryptophan), $1089 \mathrm{~cm}^{-1}$ (C-C stretching), $1390 \mathrm{~cm}^{-1}$ (C-N 
rocking), $\quad 1502 \mathrm{~cm}^{-1}$ (cytosine), $1641 \mathrm{~cm}^{-1}$ (Amide-I), $1728 \mathrm{~cm}^{-1} \quad$ (ester) and $1738 \mathrm{~cm}^{-}$ ${ }^{1}$ (lipids)(Movasaghi, Rehman et al. 2007). Furthermore, in comparison of loading with experimental Raman spectrum of pure RNA some peaks are observed which are similar in loadings of HCV samples including $720 \mathrm{~cm}^{-1}, 813 \mathrm{~cm}^{-1}, 880 \mathrm{~cm}^{-1}, 922 \mathrm{~cm}^{-1}, 1105 \mathrm{~cm}^{-1}, 1489 \mathrm{~cm}^{-1}$, and $1578 \mathrm{~cm}^{-1}$. These Raman spectral features observed in the Figure 4indicate that all these biochemical changes/Raman spectral features can be considered as markers of HCV infection as they are also present in experimental Raman spectra of pure RNA and absent in the healthy/control Raman spectra.
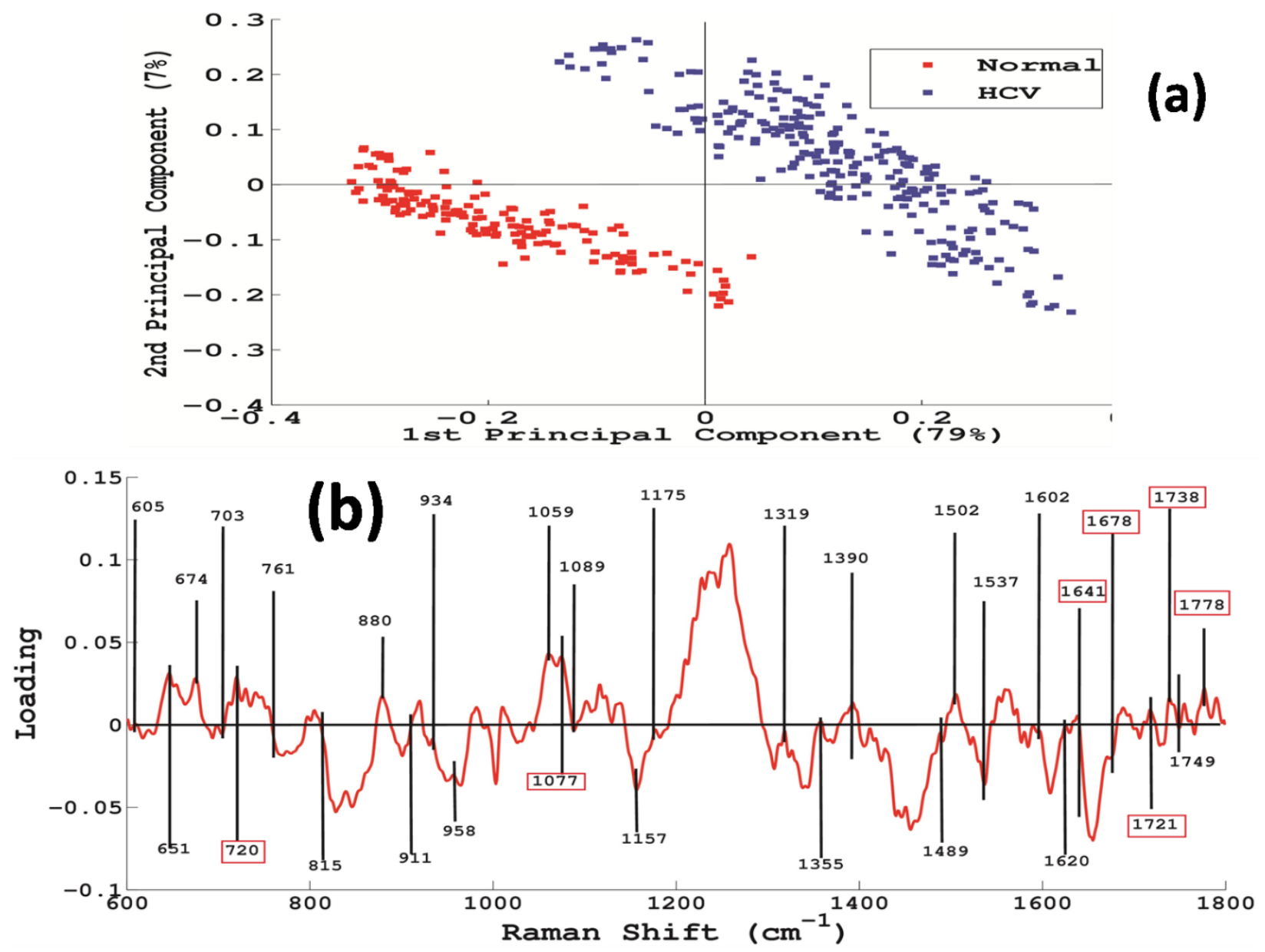

Figure 4 PCA scatter plot (a) and loadings of Raman spectral data acquired from healthy versus confirm HCV samples (b). 


\section{Conclusions}

In order to identify the biochemical changes occurring during the process of Hepatitis $\mathrm{C}$ development, Raman spectroscopy along with Principal Component analysis is employed. Raman spectral features as indicated by Principal Component analysis are hence established which can be associated with the human blood plasma samples of the infected and healthy individuals. Among others, the Raman spectral features which are observed only for the HCV positive samples include $720 \mathrm{~cm}^{-1}$ (adenine), $1077 \mathrm{~cm}^{-1}\left(\mathrm{PO}_{2}\right.$ stretching of RNA), $1678 \mathrm{C}=\mathrm{O}$ stretching mode of dGTP of RNA, $1778 \mathrm{~cm}^{-1}$ (RNA), 1641 (amide-I), $1721 \mathrm{~cm}^{-1}(\mathrm{C}=\mathrm{C}$ stretching of proteins)and $1738 \mathrm{~cm}^{-1}$ ( $\mathrm{C}=\mathrm{O}$ of ester group in lipids). These differences in Raman spectral features of blood plasma samples of the patients and healthy volunteers can be associated with the development of the biochemical changes during HCV infection.

\section{Conflict of Interest}

The authors declare that there is no conflict of interest for this research work.

\section{References}

Binoy, J., J. P. Abraham, et al. (2004). "NIR-FT Raman and FT-IR spectral studies and ab initio calculations of the anti-cancer drug combretastatin-A4." Journal of Raman Spectroscopy 35(11): 939-946.

Chan, J. W., D. S. Taylor, et al. (2006). "Micro-Raman spectroscopy detects individual neoplastic and normal hematopoietic cells." Biophysical journal 90(2): 648-656.

Cheng, W. T., M. T. Liu, et al. (2005). "Micro-Raman spectroscopy used to identify and grade human skin pilomatrixoma." Microscopy research and technique 68(2): 75-79.

D'Amico, F., F. Cammisuli, et al. (2015). "Oxidative damage in DNA bases revealed by UV resonant Raman spectroscopy." Analyst 140(5): 1477-1485.

Dukor, R. K. (2002). "Vibrational spectroscopy in the detection of cancer." Handbook of vibrational spectroscopy.

Enomoto, M., S. Nishiguchi, et al. (2001). "Comparison of real-time quantitative polymerase chain reaction with three other assays for quantitation of hepatitis C virus." Journal of gastroenterology and hepatology 16(8): 904-909.

Farquharson, S., C. Shende, et al. (2005). "Analysis of 5-fluorouracil in saliva using surface-enhanced Raman spectroscopy." Journal of Raman Spectroscopy 36(3): 208-212.

Ford, N., C. Kirby, et al. (2012). "Chronic hepatitis C treatment outcomes in low-and middle-income countries: a systematic review and meta-analysis." Bulletin of the World Health Organization 90(7): 540-550.

Frank, C. J., R. L. McCreery, et al. (1995). "Raman spectroscopy of normal and diseased human breast tissues." Analytical chemistry 67(5): 777-783.

Gretch, D. R. (1997). "Diagnostic tests for hepatitis C." Hepatology 26(S3). 
Hanlon, E., R. Manoharan, et al. (2000). "Prospects for in vivo Raman spectroscopy." Physics in Medicine \& Biology 45(2): R1.

Huang, Z., A. McWilliams, et al. (2003). "Near-infrared Raman spectroscopy for optical diagnosis of lung cancer." International journal of cancer 107(6): 1047-1052.

Jess, P. R., D. D. Smith, et al. (2007). "Early detection of cervical neoplasia by Raman spectroscopy." International journal of cancer 121(12): 2723-2728.

Kesli, R., H. Polat, et al. (2011). "Comparison of a newly developed automated and quantitative hepatitis $C$ virus (HCV) core antigen test with the HCV RNA assay for clinical usefulness in confirming antiHCV results." Journal of clinical microbiology 49(12): 4089-4093.

Kline, N. J. and P. J. Treado (1997). "Raman chemical imaging of breast tissue." Journal of Raman Spectroscopy 28(2-3): 119-124.

Krafft, C., L. Neudert, et al. (2005). "Near infrared Raman spectra of human brain lipids." Spectrochimica Acta Part A: Molecular and Biomolecular Spectroscopy 61(7): 1529-1535.

Lakshmi, R. J., V. Kartha, et al. (2002). "Tissue Raman spectroscopy for the study of radiation damage: brain irradiation of mice." Radiation research 157(2): 175-182.

Lavanchy, D. (2009). "The global burden of hepatitis C." Liver International 29(s1): 74-81.

Malini, R., K. Venkatakrishna, et al. (2006). "Discrimination of normal, inflammatory, premalignant, and malignant oral tissue: a Raman spectroscopy study." Biopolymers 81(3): 179-193.

Malini, R., K. Venkatakrishna, et al. (2006). "Discrimination of normal, inflammatory, premalignant, and malignant oral tissue: a Raman spectroscopy study." Biopolymers: Original Research on Biomolecules 81(3): 179-193.

Martin, P., F. Fabrizi, et al. (1998). "Automated RIBA hepatitis C virus (HCV) strip immunoblot assay for reproducible HCV diagnosis." Journal of clinical microbiology 36(2): 387-390.

Movasaghi, Z., S. Rehman, et al. (2007). "Raman spectroscopy of biological tissues." Applied Spectroscopy Reviews 42(5): 493-541.

Naumann, D. (1998). Infrared and NIR Raman spectroscopy in medical microbiology. Infrared spectroscopy: new tool in medicine, International Society for Optics and Photonics.

Nawaz, H., F. Bonnier, et al. (2010). "Evaluation of the potential of Raman microspectroscopy for prediction of chemotherapeutic response to cisplatin in lung adenocarcinoma." Analyst 135(12): 3070-3076.

Nawaz, H., F. Bonnier, et al. (2011). "Comparison of subcellular responses for the evaluation and prediction of the chemotherapeutic response to cisplatin in lung adenocarcinoma using Raman spectroscopy." Analyst 136(12): 2450-2463.

Nawaz, H., A. Garcia, et al. (2013). "Raman micro spectroscopy study of the interaction of vincristine with A549 cells supported by expression analysis of bcl-2 protein." Analyst 138(20): 6177-6184.

Nawaz, H., N. Rashid, et al. (2017). "Prediction of viral loads for diagnosis of Hepatitis C infection in human plasma samples using Raman spectroscopy coupled with partial least squares regression analysis." Journal of Raman Spectroscopy 48(5): 697-704.

Neugebauer, U., S. Trenkmann, et al. (2014). "Fast differentiation of SIRS and sepsis from blood plasma of ICU patients using Raman spectroscopy." Journal of biophotonics 7(3-4): 232-240.

Notingher, I., C. Green, et al. (2004). "Discrimination between ricin and sulphur mustard toxicity in vitro using Raman spectroscopy." Journal of the Royal Society Interface 1(1): 79-90.

Ostrowska, K. M., A. Garcia, et al. (2011). "Correlation of p16 INK4A expression and HPV copy number with cellular FTIR spectroscopic signatures of cervical cancer cells." Analyst 136(7): 1365-1373.

Ostrowska, K. M., A. Malkin, et al. (2010). "Investigation of the influence of high-risk human papillomavirus on the biochemical composition of cervical cancer cells using vibrational spectroscopy." Analyst 135(12): 3087-3093. 
Pachaiappan, R., A. Prakasarao, et al. (2017). High wavenumber Raman spectroscopic characterization of normal and oral cancer using blood plasma. Advanced Biomedical and Clinical Diagnostic and Surgical Guidance Systems XV, International Society for Optics and Photonics.

Pappu, R., A. Prakasarao, et al. (2017). Raman spectroscopic characterization of urine of normal and cervical cancer subjects. Advanced Biomedical and Clinical Diagnostic and Surgical Guidance Systems XV, International Society for Optics and Photonics.

Pawlotsky, J.-M. (2003). "Hepatitis C virus genetic variability: pathogenic and clinical implications." Clinics in liver disease 7(1): 45-66.

Puppels, G., H. Garritsen, et al. (1993). "Carotenoids located in human lymphocyte subpopulations and natural killer cells by Raman microspectroscopy." Cytometry Part A 14(3): 251-256.

Raeymaekers, L. (1993). "Quantitative PCR: theoretical considerations with practical implications." Analytical biochemistry 214(2): 582-585.

Ruiz-Chica, A., M. Medina, et al. (2004). "Characterization by Raman spectroscopy of conformational changes on guanine-cytosine and adenine-thymine oligonucleotides induced by aminooxy analogues of spermidine." Journal of Raman Spectroscopy 35(2): 93-100.

Saade, J., M. T. T. Pacheco, et al. (2008). "Identification of hepatitis C in human blood serum by nearinfrared Raman spectroscopy." Journal of Spectroscopy 22(5): 387-395.

Saleem, M., M. Bilal, et al. (2013). "Optical diagnosis of dengue virus infection in human blood serum using Raman spectroscopy." Laser Physics Letters 10(3): 035602.

Schiff, E. R., M. de Medina, et al. (1998). New perspectives in the diagnosis of hepatitis C. Seminars in liver disease.

Schrader, B. (2008). Infrared and Raman spectroscopy: methods and applications, John Wiley \& Sons.

Schulz, H. and M. Baranska (2007). "Identification and quantification of valuable plant substances by IR and Raman spectroscopy." Vibrational Spectroscopy 43(1): 13-25.

Shepard, C. W., L. Finelli, et al. (2005). "Global epidemiology of hepatitis C virus infection." The Lancet infectious diseases 5(9): 558-567.

Shetty, G., C. Kendall, et al. (2006). "Raman spectroscopy: elucidation of biochemical changes in carcinogenesis of oesophagus." British journal of cancer 94(10): 1460.

Sigurdsson, S., P. A. Philipsen, et al. (2004). "Detection of skin cancer by classification of Raman spectra." IEEE transactions on biomedical engineering 51(10): 1784-1793.

Stone, N., C. Kendall, et al. (2002). "Near-infrared Raman spectroscopy for the classification of epithelial pre-cancers and cancers." Journal of Raman Spectroscopy 33(7): 564-573.

Stone, N., C. Kendall, et al. (2004). "Raman spectroscopy for identification of epithelial cancers." Faraday discussions 126: 141-157.

Su, Y.-C., C.-L. Ho, et al. (2006). "Antifungal activities and chemical compositions of essential oils from leaves of four eucalypts." Taiwan Journal of Forest Science 21(1): 49-61.

Swellam, M., M. S. Mahmoud, et al. (2011). "Diagnosis of hepatitis C virus infection by enzyme-linked immunosorbent assay and reverse transcriptase-nested polymerase chain reaction: $A$ comparative evaluation." IUBMB life 63(6): 430-434.

Wood, B. R., M. A. Quinn, et al. (1998). "FTIR microspectroscopic study of cell types and potential confounding variables in screening for cervical malignancies." Biospectroscopy 4(2): 75-91. 